Key Factors Affecting Nickel Recovery during the Segregation of Laterite Ores

David E. Grimsey ${ }^{\mathrm{a} *}$ and Eric J. Grimsey ${ }^{\mathrm{b}}$, and Don C. Ibana ${ }^{\mathrm{b}}$

${ }^{a}$ BHP Billiton - Nickel West, Kalgoorlie, Australia; ${ }^{b}$ W A School of Mines, Curtin University, Kalgoorlie, Australia

*Corresponding author: david.grimsey@bhpbilliton.com

Paper presented at CIM Conference of Metallurgists, COM 17, Vancouver, August 2730, 2017 and published in Can Met Quarterly, 56(4), pp 401-9 (Invited Paper Series: Ni-Co 2107 Symposium). 


\title{
Key Factors Affecting Nickel Recovery during the Segregation of Laterite Ores
}

\begin{abstract}
The segregation process as applied to nickel laterite ores involves the formation of gaseous nickel and iron chlorides which are subsequently reduced to form ferronickel on the surface of a solid carbon reductant. A fundamental study of the process has been carried out using limonite, nontronite and garnierite ores. The study highlighted the significant impacts that ore mineralogy and carbon addition have on the amount of nickel which is segregated rather than retained within the ore due to in-situ reduction. These important aspects affecting nickel recovery and the success of the process are discussed in this paper.
\end{abstract}

Keywords: carbon reductant, chloride addition, in-situ reduction, laterite, mineralogy, nickel segregation

\section{Introduction}

Western Australian (WA) Ni laterite deposits account for 20\% of the world's laterite resource and largely remain undeveloped. Ni laterites typically consist of three increasingly weathered zones: a limonite zone, overlying a nontronite zone (also known as a transition, smectite or clay zone), and a lower garnierite zone (also known as a saprolite or serpentine zone). Limonite has the highest Fe and lowest $\mathrm{MgO}$ and $\mathrm{SiO}_{2}$ contents and typically contains $\sim 0.8-1.5 \% \mathrm{Ni}$; garnierite has the lowest Fe and highest $\mathrm{MgO}$ and $\mathrm{SiO}_{2}$ and typically contains $\sim 1.5-3 \% \mathrm{Ni}$; nontronite has an intermediate composition and typically contains $\sim 1.4-4 \% \mathrm{Ni}$.

The segregation process offers a possible alternative to current processes (HPAL, Caron, RKEF and Electric Furnace) used for the treatment of Ni laterite ores. Segregation involves extraction of Ni through chloridisation of $\mathrm{NiO}$ at $\sim 1123-1273 \mathrm{~K}$, followed by $\mathrm{Ni}$ concentration at a carbon surface through reduction of volatile $\mathrm{Ni}$ and Fe chlorides to form ferronickel. This product can be recovered from the segregated ore 
by either flotation or magnetic separation.

A significant number of studies were carried out on the segregation of Ni laterites during the 70's and 80's; reported Ni recoveries ${ }^{1}$ varied from $17-83 \%$ for limonite, 66 $70 \%$ for nontronite (one study only) and 50-90\% for garnierite ores. These studies provided important insight into the process mechanisms but many aspects remained unclear. For this reason, a detailed review of the segregation process and a fundamental study on its application to Western Australian laterites was recently carried out ${ }^{1}$; the results discussed in this paper form part of that study.

It is well known that $\mathrm{Ni}$ and Fe oxides can be reduced in-situ by carbonaceous gases during the segregation process. This will decrease Ni recovery since in-situ ferronickel cannot be chloridised for subsequent reduction onto carbon. There is little doubt that prevention of in-situ ferronickel formation is a key factor in achieving high $\mathrm{Ni}$ recoveries from the segregation process. The aim of this paper is to provide insight into how laterite composition and mineralogy, and carbon addition, affect in-situ ferronickel formation and hence the potential success of the segregation process.

\section{Experimental}

Complete experimental details are described elsewhere ${ }^{1}$. Segregation of limonite, nontronite and garnierite Ni laterite ores was carried out under standardised (5\% $\mathrm{CaCl}_{2}, 5 \% \mathrm{C}$ reductant, relative to dried ore) rather than optimised conditions, to provide a clearer assessment of the effect of mineralogy on the process. Segregation was carried out in a vibrated, vertical tube silica reactor, similar to that used by Davidson $^{2}$, but fitted for continuous measurement of oxygen pressure using a $\mathrm{SIRO}_{2} \mathrm{C} 700 ®$ probe placed just above the bed, and for continuous measurement of 
carbonaceous gas evolution using a Ritter TG05 fluid displacement meter; these additions allowed the monitoring of carbon consumption and oxygen removal.

Metal segregated from nontronite and garnierite ores was concentrated using a Davis Tube magnetic separator and the concentrate analysed for metallic content using a selective $\mathrm{Br}_{2}$ /methanol leach; metal segregated from limonite could not be magnetically concentrated and was leached directly from the calcine. Reduction of laterites to form in-situ ferronickel in the absence of chloride was also studied to contrast with segregation; Ni recovery was also determined using the selective leach.

\section{Materials}

\section{Laterites}

Nickel laterite ores (limonite, nontronite and garnierite) were provided as drill core by Heron Resources Limited from deposits associated with their Kalgoorlie Nickel Project in Western Australia. The samples were dried, split into representative samples and then roasted in air for 30 minutes at the temperature of subsequent segregation. The purpose was to reduce $\mathrm{H}_{2} \mathrm{O}$ from the $10-13 \%$ present in dried ore, down to $0.5-0.8 \%$, and also to dissociate any carbonates and to oxidise any sulphides. Chemical analyses of the resulting limonite, nontronite and garnierite calcines are shown in Table 1.

Table 1. Chemical analyses of dry nickel laterite calcines*

\begin{tabular}{ccccccccccc}
\hline wt\% & $\mathrm{NiO}$ & $\mathrm{CoO}$ & $\mathrm{Fe}(\mathrm{t})$ & $\mathrm{SiO}_{2}$ & $\mathrm{MgO}$ & $\mathrm{Al}_{2} \mathrm{O}_{3}$ & $\mathrm{CaO}$ & $\mathrm{Cr}_{2} \mathrm{O}_{3}$ & $\mathrm{MnO}^{2} \mathrm{Na}_{2} \mathrm{O}$ \\
\hline Limonite & $1.39(1.1 \% \mathrm{Ni})$ & 0.05 & 59.8 & 3.64 & 0.56 & 5.23 & 0 & 2.40 & 0.15 & 1.12 \\
Nontronite & $1.72(1.4 \% \mathrm{Ni})$ & 0.08 & 27.3 & 45.5 & 2.26 & 4.42 & 0 & 6.78 & 0.19 & 0.10 \\
Garnierite & $1.75(1.4 \% \mathrm{Ni})$ & 0.05 & 11.7 & 57.7 & 16.0 & 2.79 & 2.13 & 0.98 & 0.24 & 0.32 \\
\hline \multicolumn{7}{c}{$*$ Assays adjusted to $0 \% \mathrm{H}_{2} \mathrm{O}$; calcines actually retained 0.5-0.8\% $\mathrm{H}_{2} \mathrm{O}$ depending on roast conditions. }
\end{tabular}

The calcines were sized using a laser sizer and their mineralogy assessed using quantitative XRD, and for nontronite and garnierite, also using EDS-SEM analysis. 


\section{Limonite}

The limonite laterite was a mixture of hydrated Fe oxides (goethite and limonite) with minor hematite and spinel $\left(\mathrm{MgAl}_{2} \mathrm{O}_{3}\right)$. The limonite calcine was fine (80\% passing $60 \mu \mathrm{m})$ and contained $86 \%$ hematite (60\% Fe, Table 1). All Ni was considered evenly dispersed within hematite, based on extensive mineralogical analysis of calcined limonites from Western Australia ${ }^{3}$.

\section{Nontronite}

The nontronite laterite was essentially a mixture of the hydrated Fe silicate mineral nontronite $(\sim 46 \%)$, with quartz and minor chromite $\left(\mathrm{FeCrO}_{4}\right)$. The fine nontronite calcine (80\% passing $100 \mu \mathrm{m})$ contained $39 \% \mathrm{Fe}_{2} \mathrm{O}_{3}(27 \% \mathrm{Fe}$, Table 1$)$ as hematite and minor maghemite. The calcine also contained $46 \%$ silica (Table 1 ) as both crystalline and amorphous phases.

$\mathrm{Ni}$ was contained within the nontronite mineral. After roasting, remnant nontronite was present as finely grained/amorphous dehydroxylate of intimately mixed hematite and silica. Ni was dispersed throughout the dehydroxylate at an average grade of $1.6 \%$, most likely associated with Fe oxides. Coarser crystalline silica and chromite particles were present in the calcine but did not contain $\mathrm{Ni}$.

\section{Garnierite}

The garnierite laterite was a mixture of quartz ( 50\%), hydrated Mg Al silicate (chlorite, 16\%), hydrated Mg Fe silicate (serpentine, 7\%) and hydrated Fe oxides ( 8\%), along with minor minerals including dolomite, diopside, chromite and kaolinite.

Ni was contained mainly within the chlorite (clinochlore and nimite) and serpentine (lizardite) minerals. After roasting, chlorite dehydroxylate was present as Ni rich 
silicate veins within crystalline silica particles. The veins consisted of fine crystalline Mg-Al silicates (olivine and pyroxene) containing on average $7.7 \% \mathrm{Ni}$. Serpentine dehydroxylate was present as intimate mixtures of fine to amorphous Mg silicates, hematite and silica, containing on average $2.2 \% \mathrm{Ni}$, with appearance similar to nontronite dehydroxylate.

Overall, the fine garnierite calcine (80\% passing $120 \mu \mathrm{m})$ contained 12\% Fe (Table 1) present mostly as hematite $\left(\sim 18 \% \mathrm{Fe}_{2} \mathrm{O}_{3}\right)$, both as coarse particles and within amorphous dehydroxylate. The $58 \% \mathrm{SiO}_{2}$ (Table 1) in the calcine was present as large crystalline quartz particles, with a lesser amount present within dehydroxylates as silica and silicates.

\section{Carbon Reductant}

Metallurgical coke and activated coconut carbon were used as reductants, the latter to provide a greater carbon surface area per gram to enhance reduction. The metallurgical coke (80\% passing $280 \mu \mathrm{m}$ ) had a specific surface area of $4.3 \mathrm{~m}^{2} / \mathrm{g}$ and contained $78.3 \%$ C. The activated carbon (80\% passing $300 \mu \mathrm{m})$ had a specific surface area of $1160 \mathrm{~m}^{2} / \mathrm{g}$ and contained $88.7 \% \mathrm{C}$.

\section{Nickel Segregation}

Figure 1 shows percent recovery of Ni versus time for all three calcines segregated at $1173 \mathrm{~K}$, using $5 \%$ coke and $5 \% \mathrm{CaCl}_{2}$ relative to the dried ore. The curves are generated from integrated 'first order to a limit' rate equations fitted to experimental data ${ }^{1}$. For nontronite and garnierite, segregation of Ni was rapid at first but then slowed to a limit; limonite behaved similarly but only after an induction period caused by the initially high concentration of hematite in the calcine. Under these standardised segregation conditions, the maximum recovery of Ni was greatest for 
limonite (80\%), intermediate for nontronite (63\%) and least for garnierite (50\%).

Significantly higher Ni recoveries are predicted for nontronite and garnierite under optimised conditions, as discussed subsequently.

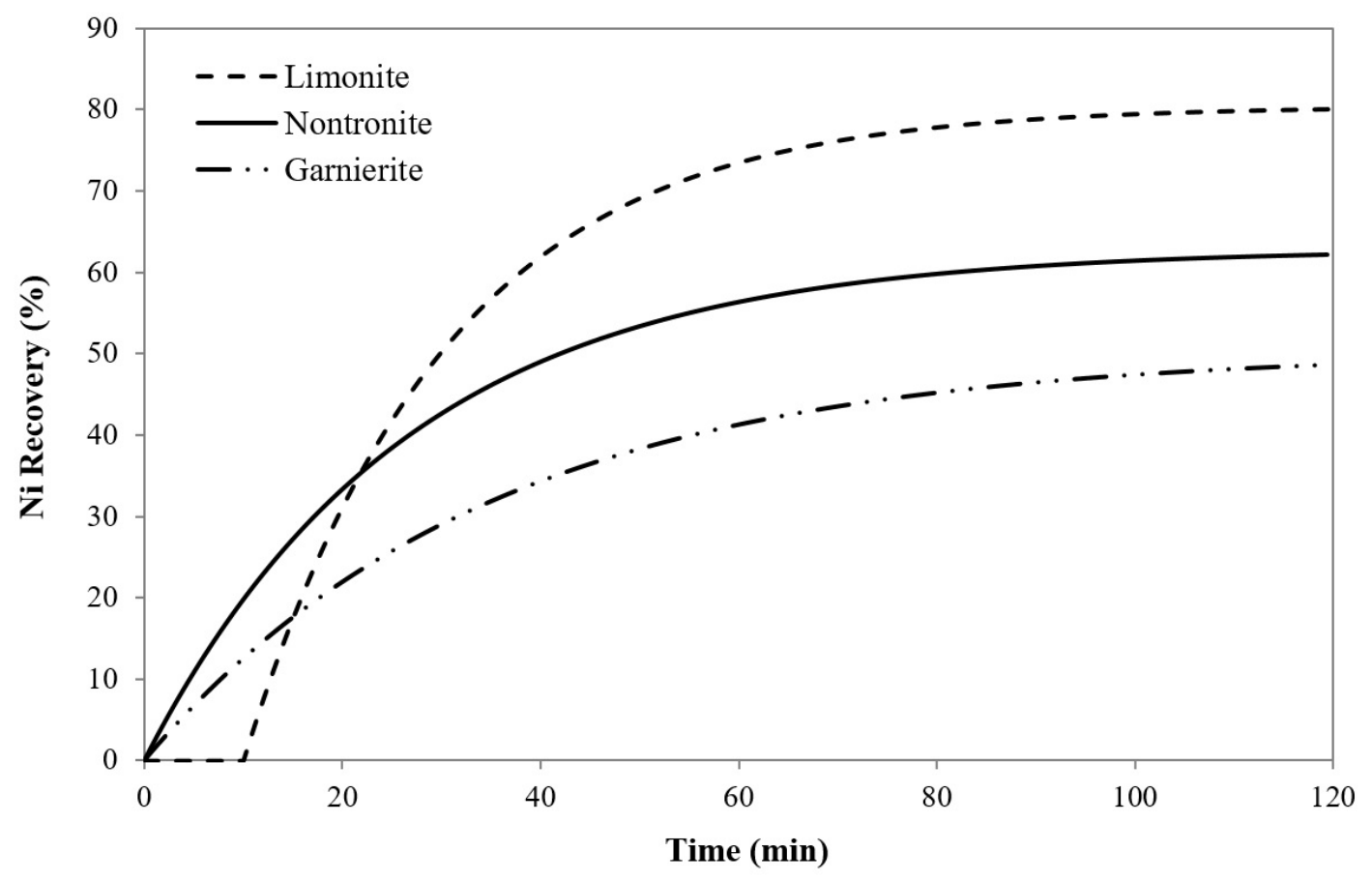

Figure 1. Ni recovery from laterites after segregation at $1173 \mathrm{~K}$ with $\mathrm{CaCl}_{2}$ and coke, each added at $5 \mathrm{~g} / 100 \mathrm{~g}$ of the dried ore.

The rate of Ni segregation for all three ores was found to be dominantly controlled ${ }^{1}$ by the rate of chloridisation of $\mathrm{NiO}$ from within the calcine (footnote ${ }^{1}$ ), via the reactions:

$$
\begin{aligned}
& \mathrm{NiO}(\mathrm{s})+2 \mathrm{HCl}(\mathrm{g}) \rightarrow \mathrm{NiCl}_{2}(\mathrm{~g})+\mathrm{H}_{2} \mathrm{O}(\mathrm{g}) \\
& \mathrm{NiO}(\mathrm{s})+\mathrm{FeCl}_{2}(\mathrm{~g}) \rightarrow \mathrm{NiCl}_{2}(\mathrm{~g})+\mathrm{FeO}(\mathrm{s})
\end{aligned}
$$

The pressure of $\mathrm{HCl}$ in the gas is usually generated by the hydrolysis of $\mathrm{CaCl}_{2}$ in the presence of silica (Reaction 3), and the pressure of $\mathrm{FeCl}_{2}$ is generated by the

\footnotetext{
${ }^{1}$ For garnierite, the rate was also controlled by the rate of $\mathrm{H}_{2}$ generation at the carbon surface by the water gas reaction.
} 
chloridisation of $\mathrm{FeO}$ with $\mathrm{HCl}$.

$$
\mathrm{CaCl}_{2}(\mathrm{l})+\mathrm{SiO}_{2}(\mathrm{~s})+\mathrm{H}_{2} \mathrm{O}(\mathrm{g}) \rightarrow \mathrm{CaSiO}_{3}(\mathrm{~s})+2 \mathrm{HCl}(\mathrm{g})
$$

\section{In-Situ Reduction}

All three calcines (Table 1) contained Fe as hematite $\left(\mathrm{Fe}_{2} \mathrm{O}_{3}\right)$, with the amounts decreasing in the order limonite (86\%) > nontronite (39\%) > garnierite (18\%). While ferronickel is being reduced onto solid carbon through segregation, the reduction of Fe oxides by carbon also occurs via a CO intermediate within the gas. The reduction of hematite to magnetite with $\mathrm{CO}$, for example, generates $\mathrm{CO}_{2}$ which then reacts with $\mathrm{C}$ to regenerate $\mathrm{CO}$ through the Boudouard reaction:

$$
\mathrm{CO}_{2}(\mathrm{~g})+\mathrm{C}(\mathrm{s}) \rightarrow 2 \mathrm{CO}(\mathrm{g})
$$

Oxygen removed from the calcine by carbon reduction is thus evolved from the reaction bed dominantly as $\mathrm{CO}$ and $\mathrm{CO}_{2}$, with the average oxygen pressure within the bed being related to the $\mathrm{CO}_{2} / \mathrm{CO}$ ratio through the equilibrium for the reaction:

$$
2 \mathrm{CO}(\mathrm{g})+\mathrm{O}_{2}(\mathrm{~g}) \rightarrow 2 \mathrm{CO}_{2}(\mathrm{~g})
$$

The average $\mathrm{CO}_{2} / \mathrm{CO}$ ratio in the evolved gas at any time during the reaction is expected to lie much closer to the equilibrium value for oxide reduction than for the Boudouard reaction. This is because oxide reduction with $\mathrm{CO}$ at segregation temperatures occurs at a much faster rate than the reaction of $\mathrm{CO}_{2}$ with solid carbon, at least for pure oxides ${ }^{4}$.

The sequence of reduction of Fe oxides in the presence of silica, from least to most stable, is: $\mathrm{Fe}_{2} \mathrm{O}_{3}$ (hematite) $\rightarrow \mathrm{Fe}_{3} \mathrm{O}_{4}$ (magnetite), $\mathrm{Fe}_{3} \mathrm{O}_{4}\left(+\mathrm{SiO}_{2}\right) \rightarrow \mathrm{Fe}_{2} \mathrm{SiO}_{4}$ (fayalite), $\mathrm{Fe}_{3} \mathrm{O}_{4}\left(+\mathrm{SiO}_{2}\right) \rightarrow \mathrm{FeSiO}_{3}\left(\right.$ ferrosilite), $\mathrm{Fe}_{3} \mathrm{O}_{4} \rightarrow$ 'FeO'(wustite) and 'FeO' $\rightarrow$ Fe. The $\mathrm{CO}_{2} / \mathrm{CO}$ ratio will decrease along with the oxygen pressure as Fe oxide reduction 
progresses during segregation.

If all oxides are pure, and in the absence of any noticeable effect of the Boudouard reaction on gas composition, the oxygen pressure would remain constant during each Fe oxide transformation, and fall stepwise as each of the Fe oxide species is reduced. However, the oxygen pressure falls continuously during reduction due to the influence of solid solutions on the activities of the species, since within the impure calcines, $\mathrm{Fe}_{3} \mathrm{O}_{4}$ is present within spinel, $\mathrm{Fe}_{2} \mathrm{SiO}_{4}$ within olivine, $\mathrm{FeSiO}_{3}$ within pyroxene and 'FeO' within monoxide. The Boudouard reaction can also have some effect on the gas composition.

If the oxygen pressure becomes low enough, simultaneous reduction of $\mathrm{FeO}$ and $\mathrm{NiO}$ from within oxides and silicates will produce in-situ ferronickel alloy; this occurs well before reduction to form pure Fe is possible.

\section{Limonite In-situ Reduction}

Limonite calcine contains $86 \% \mathrm{Fe}_{2} \mathrm{O}_{3}$ as hematite. Reduction involves the transformation of hematite to magnetite, followed by magnetite to fayalite as minor silica is consumed, and finally magnetite to wustite. Figure 2 shows the measured oxygen pressures within the gas versus reaction time for limonite calcine at $1173 \mathrm{~K}$, for:

(1) reduction with coke without chloride addition, (2) segregation with coke, and (3) segregation with activated carbon. Segregation with activated carbon was only carried out for 80 minutes compared to 120 minutes for both segregation and reduction with coke. The equilibrium oxygen pressures for the transformation of pure Fe oxide and silicate species are projected across the diagram for reference.

Figure 2 shows that the oxygen pressure profiles during reduction or segregation with 
coke are similar. However, the profile for segregation with activated carbon lies below the other two, since the extent of reduction at a given time is increased because the carbon surface area is much larger for activated carbon compared to coke. All three profiles show an initial rapid decline in oxygen pressure, but this is an artefact from the heat up of the oxygen probe. The carbonaceous content of the gas would be virtually $100 \% \mathrm{CO}_{2}$ during the initial reduction of hematite to magnetite and the true initial oxygen pressure would lie close to the $\mathrm{Fe}_{2} \mathrm{O}_{3} / \mathrm{Fe}_{3} \mathrm{O}_{4}$ equilibrium at the top of the diagram.

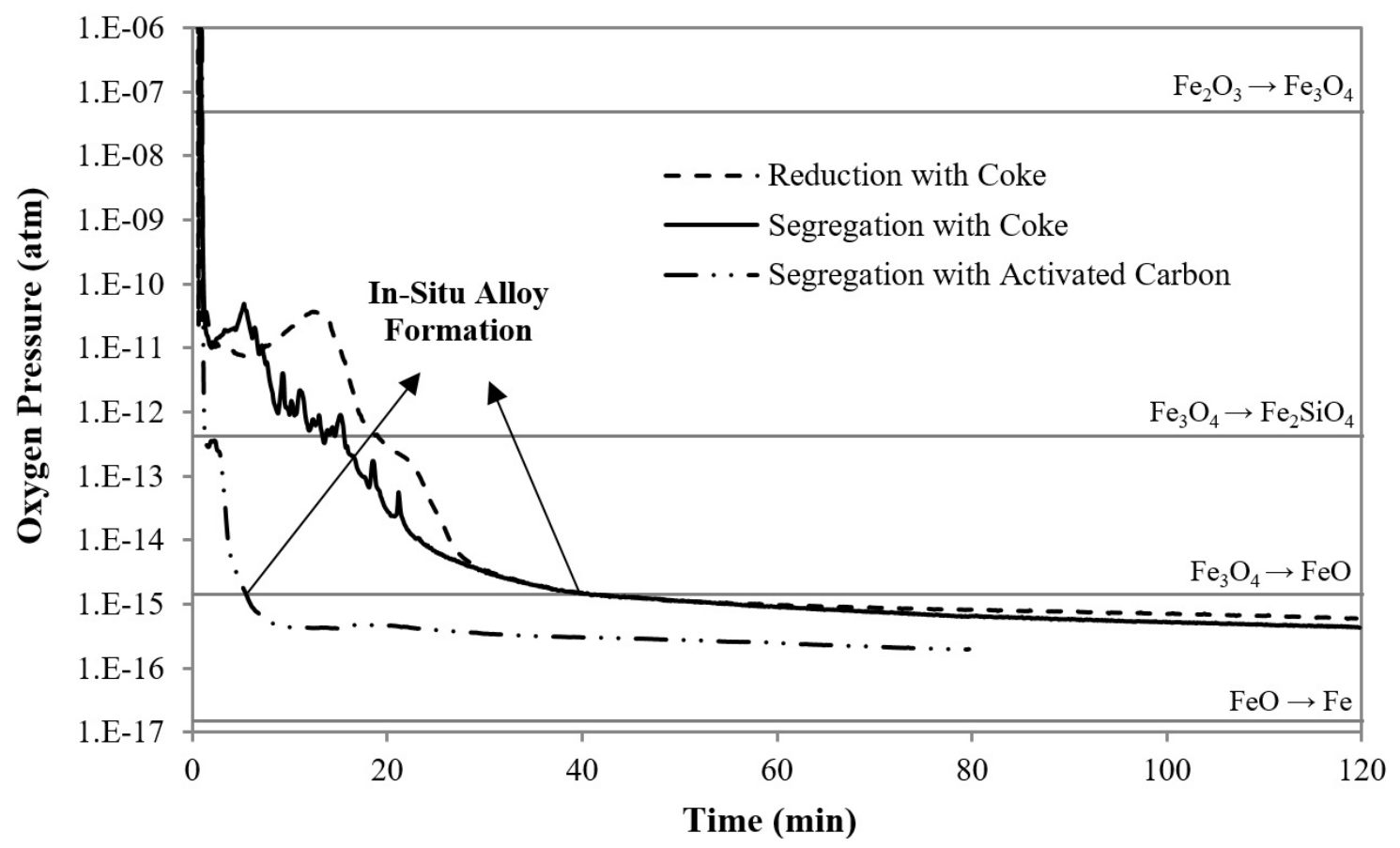

Figure 2. Oxygen pressure profile comparison, limonite, $1173 \mathrm{~K}$. Oxygen pressures for segregation are a best fit from multiple experiments. Equilibrium values for pure oxides are for reference. On-set of in-situ alloy formation is a FACTSage (v6.4) equilibrium prediction $^{1}$.

The final oxygen pressure for all three reduction scenarios remains above that for the reduction of pure 'FeO' to Fe. However, equilibrium simulation ${ }^{1}$ using FACTSage (v6.4) software predicted that in-situ reduction to form ferronickel can occur when the 
oxygen pressure falls to $1.4 \times 10^{-15}$ atm, assuming no prior removal of $\mathrm{Ni}$ from the calcine by segregation. Under this scenario, in-situ ferronickel is predicted to form after 5.5 minutes during segregation with activated carbon and after 41 minutes during segregation or reduction with coke at $1173 \mathrm{~K}$ (Figure 2).

Experimental data were consistent with these predictions. For reduction with coke in the absence of chloride, $60 \%$ of $\mathrm{Ni}$ was present as in-situ ferronickel after 60 minutes, 19 minutes after in-situ alloy is predicted to form. Significant in-situ ferronickel was also found after segregation with activated carbon, consistent with the formation of insitu alloy at 5.5 minutes, only 1 minute after the induction period for the start of limonite segregation ${ }^{1}$. The in-situ alloy was present amongst remnant Fe oxides (Figure 3); Ni recovery from segregation was limited to $67 \%$ after 120 minutes as a result.

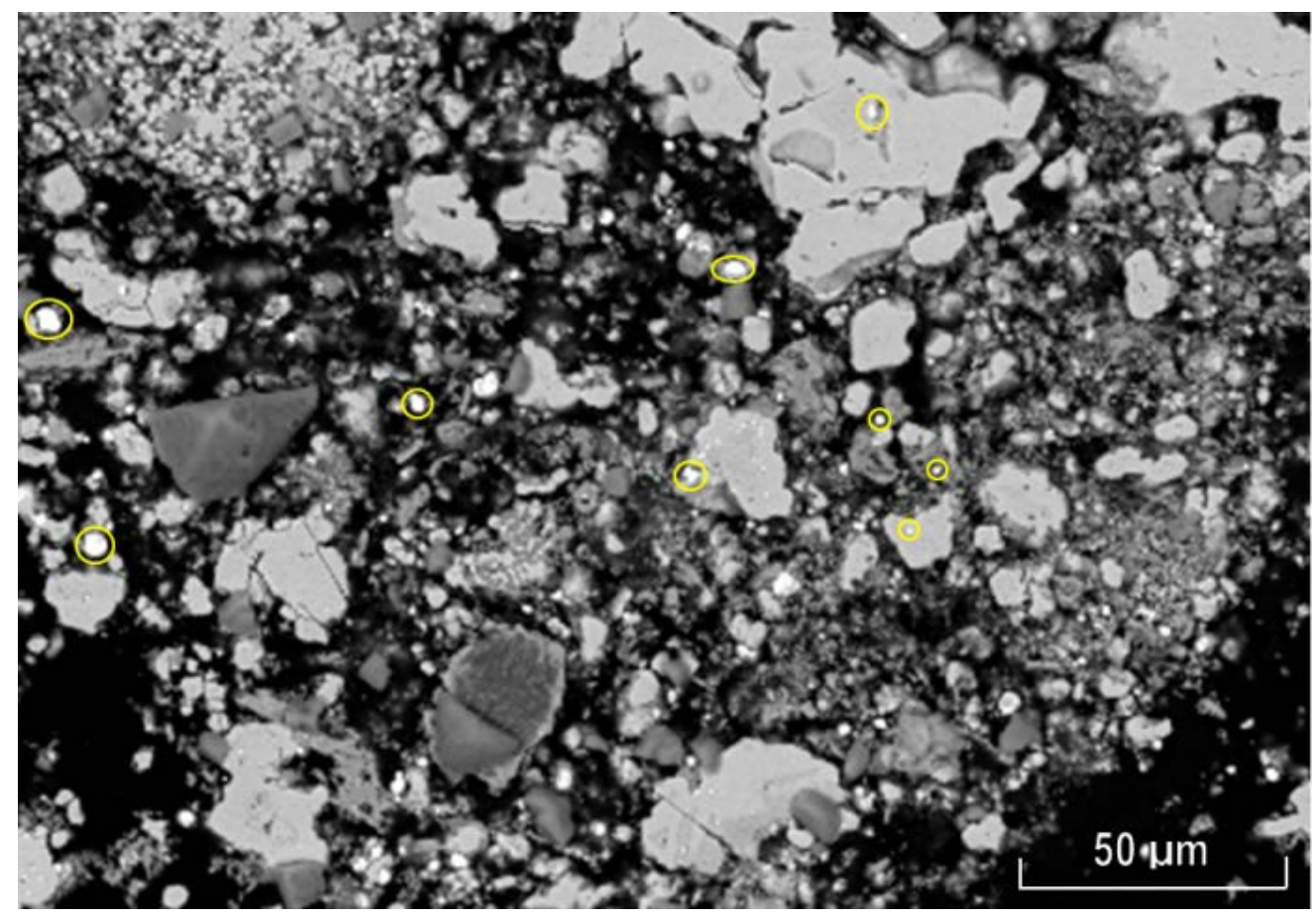

Figure 3. In-situ ferronickel (circled) within limonite calcine segregated with activated carbon at $1173 \mathrm{~K}$.

Segregation with coke commenced after 10 minutes and removed $60 \%$ of $\mathrm{Ni}$ at 41 
minutes (Figure 1), when in-situ ferronickel is first predicted to form, provided all Ni remains in the calcine. As $\mathrm{Ni}$ is removed by segregation, the critical pressure for in-situ alloy formation progressively decreases, making its formation less likely. Since in-situ ferronickel did not form during segregation with coke at $1173 \mathrm{~K}$, as confirmed by experiment, early removal of $\mathrm{Ni}$ from the calcine by segregation completely suppressed the formation of in-situ alloy under these conditions. As a result, Ni recovery from segregation increased to $80 \%$ after 120 minutes when using coke at $1173 \mathrm{~K}$, compared to $67 \%$ when using activated carbon.

\section{Nontronite In-situ Reduction}

Figure 4 shows the measured oxygen pressure profiles for nontronite calcine at $1173 \mathrm{~K}$, for: (1) reduction with coke without chloride addition and (2) segregation with coke. No segregation was carried out with activated carbon at $1173 \mathrm{~K}$. The figure shows that in contrast to limonite, much lower oxygen pressures were reached at a given time during segregation compared to reduction. It was also found that carbon consumption during segregation was 67\% higher than for reduction after 120 minutes. This confirmed that the rate of carbon gasification via the Boudouard reaction (and hence the rate of Fe oxide reduction) was significantly enhanced for nontronite calcine when chloride was present; although likely related to mineralogy, the cause requires further investigation.

Nontronite calcine contains 39\% hematite and 46\% silica, significantly less hematite and significantly more silica than for limonite calcine, with a substantial portion of silica being amorphous and in contact with Fe oxides. As a result, there is substantial reduction of magnetite to form both fayalite (in olivine) and ferrosilite (in pyroxene), as confirmed by experiment. 
Reduction of magnetite to form Fe silicates occurs at higher oxygen pressures than when the product is wustite and silicate formation can potentially buffer the oxygen pressure above that necessary for in-situ alloy formation. For reduction of nontronite with coke at $1173 \mathrm{~K}$, without chloride addition, all hematite is reduced to magnetite after 20 minutes, and then silicates form. The oxygen pressure continues to fall as reduction proceeds but remains above the critical oxygen pressure for in-situ alloy formation ( $\left.7 \times 10^{-15} \mathrm{~atm}\right)$, even after 120 minutes of reduction with coke at $1173 \mathrm{~K}$ (Figure 4). This was confirmed by experiment since no ferronickel was found in this case.



Figure 4. Oxygen pressure profile comparison, nontronite, $1173 \mathrm{~K}$. Oxygen pressures for segregation are a best fit from multiple experiments. On-set of in-situ alloy formation is a FACTSage (v6.4) equilibrium prediction ${ }^{1}$.

For segregation of nontronite with coke at $1173 \mathrm{~K}$, the rate of Fe oxide reduction is significantly faster than in the absence of chloride; the conversion of hematite to 
magnetite is complete after 5 minutes and the majority of magnetite is reduced to form silicates after 30 minutes. The oxygen pressure then continues to fall but with little gas evolution, as likely the remaining magnetite is slowly reduced from within spinel solid solutions.

The critical oxygen pressure for in-situ alloy formation is reached after 27 minutes (Figure 4) but by this time, $40 \%$ of $\mathrm{Ni}$ has been removed from the calcine by segregation (Figure 1). This removal completely suppressed the formation of in-situ ferronickel during segregation, as confirmed by experiment. Ni recovery was $63 \%$ after segregation with coke for 120 minutes at $1173 \mathrm{~K}$ (Figure 1), with unsegregated Ni present as $\mathrm{NiO}$ within Fe silicates (ferrosilite and minor fayalite), in remnant nontronite dehydroxylate.

When the temperature of segregation with coke was increased to $1223 \mathrm{~K}$, the recovery of $\mathrm{Ni}$ increased to 71\%, with very minor in-situ alloy observed. When coke was replaced by activated carbon at $1223 \mathrm{~K}$, the recovery fell marginally to $67 \%$, and in-situ ferronickel was observed amongst the Fe silicates within remnant nontronite dehydroxylate.

\section{Garnierite In-situ Reduction}

Garnierite calcine contained the least amount of hematite (12\%) and the highest amounts of silica (58\%) and magnesia (16\%); the latter present mainly as finely crystalline Mg-Al silicates within chlorite dehydroxylate and Mg silicates within serpentine dehydroxylate. At least half of the silica was present as coarse crystalline particles. The oxygen pressure profiles for both reduction and segregation with coke at $1173 \mathrm{~K}$ were similar, with minor enhancement of the carbon gasification rate during segregation. No segregation was carried out with activated carbon at $1173 \mathrm{~K}$. 
Figure 5 compares the oxygen pressure profile of garnierite with those for limonite and nontronite during segregation with coke at $1173 \mathrm{~K}$. The oxygen pressure at which insitu alloy can form (3.9 $\left.\times 10^{-15} \mathrm{~atm}\right)$ is higher for garnierite compared to the other calcines and is reached earlier, after 7.5 minutes, when only $10 \%$ of Ni has been removed by segregation (Figure 1). As a result, significant in-situ ferronickel formed when segregating garnierite calcine with coke at $1173 \mathrm{~K}$, as confirmed by experiment, with the recovery of Ni limited to 50\% after 120 minutes (Figure 1).

The recovery of Ni increased to 65\% for segregation with coke at $1223 \mathrm{~K}$ but fell to $48 \%$ when activated carbon was used at this temperature. In-situ ferronickel formed in all segregation experiments conducted with garnierite, using either coke or activated carbon, with the majority of unrecovered Ni present as in-situ reduced alloy amongst remnant chlorite and serpentine dehydroxylates.



Figure 5. Oxygen pressure profiles from the segregation with coke of limonite, nontronite and garnierite at $1173 \mathrm{~K}$. 


\section{Discussion}

\section{In-situ Reduction}

The critical oxygen pressure at which in-situ ferronickel can form depends on the activities of both $\mathrm{NiO}$ and $\mathrm{FeO}$ within the calcine, which are related to the calcine composition and mineralogy. Oxide activities were not measured in this work; rather critical oxygen pressures were predicted as a first approximation using equilibrium simulations.

Since $\mathrm{NiO}$ is less stable than $\mathrm{FeO}$, calcines containing higher concentrations of $\mathrm{NiO}$ will tend to have higher critical oxygen pressures which favour in-situ ferronickel formation. Nontronite calcine contained more $\mathrm{NiO}$ than limonite (cf. 1.72, 1.39\%, Table 1) and was predicted to have a higher critical pressure at $1173 \mathrm{~K}$ (cf. $\left.1.7 \times 10^{-15}, 1.4 \times 10^{-15} \mathrm{~atm}\right)$. In contrast, nontronite and garnierite calcines contained similar $\mathrm{NiO}$ (cf. 1.72, 1.75\%), but the predicted critical pressure for garnierite at $1173 \mathrm{~K}$ was significantly higher (cf. $3.9 \times 10^{-15}, 1.7 \times 10^{-15}$ atm) due to the relatively high, localised concentration of Ni within chlorite and serpentine dehydroxylates of 7.7 and 2.2\% respectively. Such high localised Ni concentrations may be present for other roasted garnierite ores, since chlorite and serpentine are the common minerals within garnierite which contain $\mathrm{Ni}$.

The extent of in-situ ferronickel formation for a particular calcine depends on both the oxygen profile generated within the carbonaceous gas during reduction, as determined by the sequence of Fe oxide reduction reactions, and the rate of carbon consumption. At a given carbon consumption, the oxygen pressure especially depends on the amounts of hematite and silica in the calcine and whether these have intimate contact such that silicates can form. Thus the potential for in-situ alloy formation during segregation is affected by the laterite calcine composition and mineralogy, as well as the carbon 
addition.

Increase in temperature or carbon surface area enhances the carbon gasification rate via the Boudouard reaction. This increases the Fe oxide reduction rate and lowers the oxygen pressure at a given time. If the rate of carbon consumption is not too high, the formation of silicates can arrest the fall in oxygen pressure and suppress in-situ reduction, as observed for nontronite in the absence of chloride (Figure 4). It thus seems feasible that blending ores to promote silicate formation may be beneficial during segregation, as observed by Davidson ${ }^{2}$.

For a specific reductant, an increase in C/Fe ratio within the charge will increase the rate of reduction of Fe oxides and lower the oxygen profile, thus increasing the potential for in-situ reduction. The C/Fe ratio for garnierite (0.42) is 5 times greater than for limonite (0.08) and as shown in Figure 5, the oxygen profile for garnierite is significantly lower than for limonite. Nontronite has an intermediate C/Fe ratio (0.18) and shows an intermediate oxygen profile, at least in the range 5-60 minutes; however, the oxygen profile is also affected by the catalytic effect from the presence of chloride, which appears unique to the nontronite mineralogy (Figure 4).

\section{Segregation}

The initial rate of Ni segregation is very rapid (Figure 1). This seems fundamental to the success of the process since removal of $\mathrm{Ni}$ from the calcine progressively reduces the potential for in-situ alloy formation by lowering the critical oxygen pressure required for its formation. The rapid initial segregation also minimises the amount of $\mathrm{NiO}$ that remains unsegregated within solid solutions or silicates. Such $\mathrm{NiO}$ is difficult to chloridise towards the end of the segregation process when the $\mathrm{NiO}$ 
reactivity is low and the $\mathrm{HCl}$ pressure is minimal, since little $\mathrm{H}_{2} \mathrm{O}$ remains for hydrolysis of $\mathrm{CaCl}_{2}$.

All segregation was carried out using standardised additions of $\mathrm{CaCl}_{2}$ and activated carbon or coke. Under comparable conditions, segregation recoveries of Ni were always lower when using activated carbon because of the formation of in-situ ferronickel. Ni recoveries were also lower for reduction in the absence of chloride compared to segregation, mainly because finely dispersed in-situ ferronickel was difficult to recover from calcine by leaching ${ }^{1}$.

The highest Ni recovery achieved for limonite under standardised segregation conditions was $80 \%$ using coke at $1173 \mathrm{~K}$. No in-situ ferronickel formed and this recovery appears close to the maximum for limonite, based on similar recoveries achieved by others for temperatures up to $1273 \mathrm{~K}^{5}$. Ultimately, segregation recovery from limonite appears limited by the large mass of Fe oxides into which remnant $\mathrm{NiO}$ can dissolve and become unreactive.

The highest standardised Ni recovery achieved for nontronite was 79\% using coke at $1273 \mathrm{~K}$ (40 K above the initial calcine sintering temperature), compared to $63 \%$ at 1173 $\mathrm{K}$, with no loss due to in-situ ferronickel. The higher temperature increases the rate of chloridisation (and hence segregation) which likely reduces the amount of $\mathrm{NiO}$ ultimately captured within crystallising Fe silicates. Higher recoveries from nontronite may also be possible by enhancing the initial rate of chloridisation through addition of $\mathrm{MgCl}_{2}$ along with $\mathrm{CaCl}_{2}$. $\mathrm{MgCl}_{2}$ produces a much higher $\mathrm{HCl}$ pressure than $\mathrm{CaCl}_{2}$ during hydrolysis; however, it is quickly consumed and $\mathrm{CaCl}_{2}$ is still required to sustain segregation. 
The highest standardised Ni recovery from garnierite was 65\% using coke at $1223 \mathrm{~K}$, with recovery mainly limited by in-situ ferronickel which remained within both serpentine and chlorite dehydroxylates. Others ${ }^{6}$ have achieved $90 \%$ Ni recovery from garnierite using 2\% C as coke, much lower than the standardised 5\% C used here. This likely minimised in-situ alloy formation by significantly raising the oxygen profile. Similar high recoveries seem possible using lower $\mathrm{C}$ with the present ore, since excluding the Ni lost in-situ as ferronickel, only 13\% Ni remained within silicates, leaving $\sim 87 \%$ potentially amenable to segregation.

\section{Conclusion}

High recoveries of $\mathrm{Ni}$ are possible from laterite ores using the segregation process provided in-situ reduction of ferronickel by the carbonaceous reaction gas can be suppressed. The potential for in-situ reduction depends largely on the reactivity of $\mathrm{NiO}$ in the calcine and the oxygen profile which is generated within the reaction gas during the segregation process. If $\mathrm{Ni}$ can be removed from the calcine by segregation before the oxygen pressure in the reaction gas becomes low enough to reduce ferronickel in-situ, segregation can be successful. This paper provides an understanding of the impact that laterite composition and mineralogy as well as carbon addition and temperature have on this process requirement, as a guide to achieving high $\mathrm{Ni}$ recoveries from laterite ores using the segregation process.

\section{References}

1. D. E. Grimsey: 'An investigation of the segregation process applied to Western Australian nickel laterites', PhD thesis, Curtin University, Perth, WA, AUS, 2015.

2. R. Davidson: 'Nickel segregation research at Anglo American Research Laboratories. Part 4. The role of iron oxides in nickel segregation', Proc. Nickel 
Segregation, San Francisco, CA, USA, Feb 1972, The AIME Metallurgical Society, 108-129.

3. M. Landers, M. Grafe, R. J. Gilkers and M. A. Wells: 'Nickel distribution and speciation in rapidly dehydroxylated goethite in oxide-type laterite ores: XAS and TEM spectroscopic (EELS and EFTEM) investigation', Aust. J. Earth. Sci., 2009, 58, 745-765.

4. O. M. Fortini and R. J. Fruehan: 'Rate of reduction of ore-carbon composites: Part I. Determination of intrinsic rate constants’, Metall. Mater. Trans. B., 2005, 36, 865-872.

5. S. Warner, R. Sridhar and H. F. Bakker: 'Thermal constraints on the segregation of nickel from laterite ores', Proc. Nickel Segregation, San Francisco, CA, USA, Feb 1972, The AIME Metallurgical Society, 241-264.

6. A. Ericson, J. Svensson and K. Ishii: 'Development of the MINPRO-PAMCO Nickel Segregation Process', J. of Metals, 1984, 36, 42-46.

\section{Acknowledgements}

The authors would like to express their appreciation to Heron Resources for providing the laterite ores used in this study and to the Mineral Research Institute of Western Australian and the Australian Government for the provision of $\mathrm{PhD}$ scholarships for DEG. 